court chose to ignore what everyone else considered obvious. It caricatured the rule of the prudent man and found, surprise of surprises, that Mr. Darrow was a "prudent man."

Unfortunately the Supreme Court ${ }^{10}$ refused to swallow this argument. The majority pointed out that talking in terms of the negligence test, the "prudent man" rule was irrelevant; Mr. Darrow had explicitly authorized his employee's conduct. Justice Black proposed a compromise: Darrow was wrong, but let's give the rule prospective application only. ${ }^{11}$ But the rest of the Court voted him down. Reversing the Court of Appeals, the Supreme Court said, in effect, that a trustee may not authorize his employees to act in a manner forbidden to him. Undoubtedly, the court was right. But nobody seemed very happy about itleast of all, Mr. Darrow.

\title{
FORCING PREFERRED DIVIDENDS: THE CHICAGO GREAT WESTERN SETTLEMENT
}

The declaration of corporate dividends is usually considered a matter within the sound discretion of the corporate directors. Courts have traditionally been reluctant to interfere with this discretion unless it is shown that the action of the directors in declaring or refusing to declare a dividend is fraudulent, in bad faith, oppressive, or clearly and extremely unreasonable. ${ }^{1}$ Thus stockholders suing to compel a declaration of dividends must meet a severe burden of proof. The probability of their success is diminished by two practical considerations. One is that the principal sources of evidence are the defendant corporation's officers and directors. The other is that the defendants are backed by the corporate pocketbook and prestige.

However, the rarity of recorded stockholder success in dividend cases does not necessarily indicate that the stockholder suit fails to offer adequate protection to those who are entitled to relief. Corporate transactions that are used to

- It may be noted that two circumstances around which the rule was formulated have changed. One is a growing expectation and demand that experts live up to their vaunted expertise and be judged, accordingly, by a higher standard than that of the prudent man. The other is that fiduciaries are now compensated for their services. See, e.g., Speight v. Gaunt, 22 Ch. D. 727 (1883) (non-compensation of fiduciaries). This payment can be regarded, at least in part, as remuneration for the added responsibility which the hired expert is expected to assume.

${ }^{10}$ Mosser v. Darrow, 341 U.S. 267 (1951).

11 Great Northern Ry. Co.v. Sunburst Oil and Refining Co., 287 U.S. 358 (1932), cited by Justice Back, merely held that no Federal Constitutional provision compelled state courts to give retroactive effect to their decisions. Refusing to give retroactive application can be justified when a case is overruled on which people have relied, or where a rule is formed which differs from established expectations. The Mosser case neither overruled any case nor defeated any established expectations.

${ }^{1}$ See Minority Shareholder Suits to Compel Declaration of Dividends, 64 Harv. L. Rev. 299 (1950); Dividend Rights of Non-Cumulative Preferred Stock, 61 Yale L.J. 245 (1952). 
justify a policy of nonpayment of dividends will be scrutinized, not only with regard to their effect on the corporation as a business entity, but also in terms of their effect on the various classes of stockholders involved. ${ }^{2}$ This comment describes an instance in which noncumulative preferred stockholders were able to obtain a favorable settlement by demonstrating that certain otherwise justifiable expenditures had an unreasonably detrimental effect on their class of stock.

\section{The Corporate Programs and Dividend Policy}

The corporation involved in this case is the Chicago Great Western Railway Company. ${ }^{3}$ The Great Western, an Illinois corporation, emerged from a reorganization ${ }^{4}$ in 1941 with the following capital structure as approved by the court (Table I).

\section{TABLE I}

\section{LONG TERM DEBT}

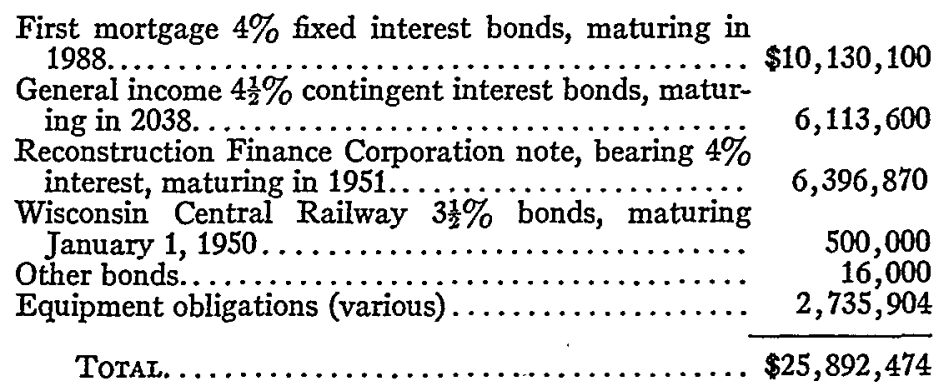

\section{CAPITAL STOCK}

366,104 shares of $\$ 50$ par value $5 \%$ preferred stock... $\$ 18,305,200$

352,639 shares of $\$ 50$ par value common stock........ $17,631,950$

Total........................... $\frac{17,937,150}{35,931,950}$

Dividends on the preferred stock were to be cumulative but only to $15 \%$ of par value, or $\$ 7.50$ per share. Preferred stock dividends were first declared in September of 1942, and were thereafter paid regularly up to and including

2 See Minority Shareholder Suits to Compel Declaration of Dividends, 64 Harv. I. Rev 299, 303-304 (1950); Dividend Rights of Non-Cumulative Preferred Stock, 61 Yale L.J. 245 (1952); Kehl, Corporate Dividends 167-69 (1941).

${ }^{3}$ The Great Western is classified by the Interstate Commerce Commission as a Class I railroad. For history and physical description, see Moody's Manual of Investments 661-72 (1951).

4 The Chicago Great Western Railroad Company (predecessor company) was incorporated under Illinois Law in 1909 as successor by reorganization to the old Chicago Great Western Railway. A low level of earnings during the depression and the failure of earnings to improve after 1932 forced the road into bankruptcy in 1935 . See In re Chicago Gt. West. R. Co., 29 F. Supp. 149 (N.D. Ill., 1939), 32 F. Supp. 217 (N.D. III., 1940); Chicago Gt. West. R. Co. Reorganization, 228 I.C.C. 585 (1938), 233 I.C.C. 63 (1939), 242 I.C.C. 698,747 (1940), 247 I.C.C. 217 (1941). 
March 1946. After that date no dividends were declared until December 1, 1949. On March 31, 1948, the maximum accumulation of $\$ 7.50$ per share was reached on the preferred stock. At this date, the preferred stock became in effect noncumulative. $^{5}$

One month after the maximum accumulation had been reached on the preferred stock, the Railway filed with the Interstate Commerce Commission a plan by which preferred shareholders would be given the option of exchanging one share of preferred stock for a $\$ 20$ par value $4 \frac{1}{2} \%$ unsecured income debenture, maturing in 2049 , and one-fifth of a share of common stock. The interest on the debentures was to be payable out of income which remained after deductions for fixed charges, interest on general income bonds, capital requirement, and sinking funds for the first mortgage and general income bonds. The debenture interest was to be cumulative to the extent of $13 \frac{1}{2} \%$.

The stated purpose of the plan was to give to those preferred shareholders who desired it an opportunity to receive some immediate income on their investment. The Railway claimed that a declaration of preferred dividends seemed unlikely for an indeterminate period because the corporate management had embarked on three extensive programs: (1) increased expenditures for maintenance of way and structures; (2) dieselization of the road's motive power; and (3) retirement of a substantial part of the Railway's long term debt in advance of maturity.

In March, 1949, Harris, a preferred stockholder, filed suit in a Chicago Federal court against the Railway, and three months later Zimmerman and other preferred stockholders also filed suit in the same court. After various motions to dismiss, ${ }^{6}$ the two suits were consolidated before Judge Barnes. ${ }^{7}$

5 No dividends were ever declared on the common stock.

${ }^{6}$ Harris held an amount of stock on which exactly $\$ 3,000$ of unpaid dividends had accumulated. A sum that exceeds $\$ 3,000$ is required for federal jurisdiction. 62 Stat. 930 (1948), 28 U.S.C.A. $\$ 1332$ (1951). Harris had not charged a conspiracy among the corporate directors as had Zimmerman, nor had he asked specifically for declaration of the dividends passed and unaccumulated. Harris was prepared to argue, in the face of a holding to the contrary in Giesecke v. Denver Tramway Corp., 81 F. Supp. 957 (D. Del., 1949), that his suit was a true class action to enforce a joint or common right, and that therefore the claims of the class could be aggregated to obtain the necessary jurisdictional amount. The Denver Tramway case reached its result by finding that (1) the plaintiff's interest was separate in that he could have brought suit alone if he had had the necessary amount, and (2) although the plaintiff was suing to compel directors to declare a common fund, it was a fund in which each stockholder would have a separate and distinct interest. The Denver Tramway case seems to place an unnecessary obstacle in the already rocky path of the plaintiff stockholder. A dividend can be declared only for the whole class of stockholders. The individual stockholder sues to enforce a declaration of dividends in favor of the whole class. The character of the right sought to be enforced for the class may thus be considered, with perhaps even more logic than in the Denver Tramway case, to be "joint, or common" under Rule 23(a) of the Federal Rules of Civil Procedure, and therefore to allow an aggregation of the claims of the class. Williams v. Green Bay \& West. R. Co., 68 F. Supp. 509 (S.D.N.Y., 1946) involved debentures closely analogous to stock in that they carried as "interest" a contingent portion of annual net income to be ascertained and declared in the sound discretion of directors, and they had no fixed date of maturity. Following the dismissal of an action by a debenture holder to enforce the declaration of in- 
The substance of the Zimmerman complaint was as follows: By the end of 1946, a particular group of common stockholders had purchased a controlling interest in the Railway. This group wanted to enhance the value of the common stock by eliminating or reducing the amount of preferred stock outstanding. They were informed that direct open market purchase by the Railway of its own preferred stock was prohibited by an Illinois statute. ${ }^{8}$ The group thereupon devised the above-described plan of exchanging debentures and common stock for preferred stock with the intent of subsequently causing the Railway to retire the debentures by open market purchases. Since there would be no incentive for preferred shareholders to make the exchange as long as regular dividends were being declared, the group caused the Railway to embark on costly and unnecessary programs of maintenance, dieselization and debt retirement. The programs were intended to serve as an excuse for the withholding of preferred dividends for an indefinite period. Moreover, once the full accumulation on the preferred stock had been reached, further undistributed earnings could be retained for the exclusive benefit of the common stockholders.

The complaint sought to compel the resumption of regular annual dividends on the preferred stock; to compel the payment of both the accumulated arrearages of $\$ 7.50$ per share and the dividends undeclared after March 31,1948; ${ }^{9}$ and to compel withdrawal of the exchange plan.

The preferred stockholders were prepared to show that the Railway had sufficient accumulated earnings to pay dividends during most of the period between March 1946, and December 1949. The regular annual dividend on the preferred stock would have been $\$ 2.50$ per share, or $\$ 915,260$. The Railway's net income $\mathrm{e}^{10}$ and surplus ${ }^{11}$ record for the $1945-50$ period was as shown in Table II.

The Railway's contention was that the maintenance, dieselization and debt retirement programs which had prevented the declaration of preferred dividends were sound and reasonable corporate transactions.

The program of increased expenditures for maintenance was attributed to the failure during the war years to rehabilitate depreciated track, roadbeds and

terest on the debentures, a second holder brought action for the same relief. The court held: "The whole body of Class B Debenture holders being entitled to dividends only in common, the attempt to enforce the declaration of such dividends by some on behalf of all was a true class suit and the dismissal therefore was conclusive on all." Ibid., at 512 . In the instant case, the Railway initially moved to dismiss the Harris complaint on the authority of the Denver Tramway case. It then withdrew its motion and Zimmerman moved to dismiss. Once the suits were consolidated, the question did not arise again.

7 Harris v. Davidson, Consolidated Civil Action No. 49 C 462 (N.D. Ill.).

8 "[I]t shall not be lawful for such corporation [i.e., railroad] to use any of the funds thereof in the purchase of its own stock. ..."Ill. Rev. Stat. (1951) c. 114, §14.

9 These dividends, which were not accumulated, eventually amounted to $\$ 4.061$ per share.

10 From 1942 to 1944 the Railway's net income was well above two million dollars per year.

11 Earned surplus appropriated rose steadily from $\$ 4,400,000$ in 1945 to $\$ 7,400,000$ in 1949. 
other structures. ${ }^{12}$ During the 1945-49 period expenditures for maintenance (both normal and deferred) increased sharply (Table III).

The dieselization program was begun in 1947 and until 1949 was financed under conditional sales contracts calling for initial payments of roughly $25 \%$ and annual payments over a period of seven to ten years. The program was substantially completed in 1949 when additional diesels were purchased under equipment trusts at $2.75 \%$ interest. The trusts called for down payments of $15 \%$ on a cost of $\$ 5,900,000$ and $\frac{1}{10}$ of $1 \%$ on a cost of $\$ 2,110,000$, with annual pay-

TABLE II

\begin{tabular}{c|c|c}
\hline \hline Date & Net Income & $\begin{array}{c}\text { Earned Surplus Un- } \\
\text { appropriated, as } \\
\text { of Dec. 31 }\end{array}$ \\
\hline $1945 \ldots \ldots \ldots \ldots \ldots \ldots$ & $\$ 1,645,930$ & $\$ 4,181,473$ \\
$1946 \ldots \ldots \ldots \ldots \ldots \ldots$ & 824,343 & $4,155,778$ \\
$1947 \ldots \ldots \ldots \ldots \ldots \ldots$ & $1,581,730$ & $5,479,590$ \\
$1948 \ldots \ldots \ldots \ldots \ldots \ldots$ & $2,882,080$ & $8,332,976$ \\
$1949 \ldots \ldots \ldots \ldots \ldots \ldots$ & $1,879,160$ & $9,298,175$ \\
$1950 \ldots \ldots \ldots \ldots \ldots \ldots$ & $2,885,532$ & $10,216,574$ \\
\hline
\end{tabular}

TABLE III

\begin{tabular}{c|r|r|r}
\hline \hline Date & $\begin{array}{c}\text { Maintenance } \\
\text { Expense* }\end{array}$ & $\begin{array}{c}\text { Capital } \\
\text { Investment }\end{array}$ & \multicolumn{1}{|c}{ Total } \\
\hline $1945 \ldots \ldots \ldots \ldots$ & $\$ 4,224,955$ & $\$ 593,931$ & $\$ 4,818,886$ \\
$1946 \ldots \ldots \ldots \ldots$ & $4,220,909$ & 416,806 & $4,637,715$ \\
$1947 \ldots \ldots \ldots \ldots$ & $4,433,437$ & 408,623 & $4,842,060$ \\
$1948 \ldots \ldots \ldots \ldots$ & $\mathbf{5}, 396,362$ & 803,976 & $6,200,338$ \\
$1949 \ldots \ldots \ldots \ldots$ & $7,064,561$ & $1,318,838$ & $8,383,399$ \\
\hline
\end{tabular}

* Including depreciation and amortization of defense projects.

ments extended over a period of $13 \frac{1}{2}-15$ years. In addition, the $\$ 6,000,000$ unpaid balance of the conditional sales contracts was refinanced under the equip-

12 The Railway considered its 780 miles of track between Chicago, St. Paul and Kansas City as main line, with an average life of 25 years. This would require a renewal of about 31 track miles each year. In the eight years since 1941 the average main line renewals amounted to only 22.5 track miles, or an annual average deficiency of 8.5 track miles. For the eight-year period, the "deferred" maintenance in rail amounted to 68 miles on the main line. In addition, it was felt that bridges, other track and structures were in need of repair.

In January 1948, a "five year plan" for rehabilitation of the road was worked out. This plan was revised upward in January 1949, when the Railway estimated the total cost of making up the deferred maintenance, on the basis of the January 1949, price level, at approximately $\$ 15,000,000$. It was planned to make up the deferred maintenance at the rate of $\$ 3,000,000$ per year for five years over and above normal maintenance. The $\$ 15,000,000$ figure included expenditures for both maintenance expense and capital investment. See ICC Examiner Howard's proposed report on the application of the Chicago Gt. West. Ry. Co., F.D. 16068, sheets 5, 6 (Aug. 24, 1949). 
ment trusts. The trusts required annual payments of $\$ 930,000$ as compared with annual conditional sale payments of $\$ 2,250,000$ in 1948 and $\$ 1,900,000$ in 1949.

The program of debt retirement is summarized in Table IV.

TABLE IV*

[In Thousands]

\begin{tabular}{|c|c|c|c|c|c|c|c|}
\hline \multirow[b]{2}{*}{ Date } & \multicolumn{2}{|c|}{$\begin{array}{c}\text { FIRST MORTGAGE } \\
\text { BONDS }\end{array}$} & \multicolumn{2}{|c|}{$\begin{array}{c}\text { GeNerAI INCOME } \\
\text { BONDS }\end{array}$} & \multirow{2}{*}{$\begin{array}{c}\text { RFC } \\
\text { NoIE } \\
\text { INo } \\
\text { DIs- } \\
\text { CoUns] } \dagger\end{array}$} & \multicolumn{2}{|c|}{ Totals } \\
\hline & $\begin{array}{c}\text { Par Value } \\
\text { of Debt } \\
\text { Retired }\end{array}$ & $\begin{array}{c}\text { Cash Dis- } \\
\text { burse- } \\
\text { mentst }\end{array}$ & $\begin{array}{l}\text { Par Value } \\
\text { of Debt } \\
\text { Retired }\end{array}$ & $\begin{array}{l}\text { Cash Dis- } \\
\text { burse- } \\
\text { mentst }\end{array}$ & & $\begin{array}{l}\text { Par Value } \\
\text { of Debt } \\
\text { Retired }\end{array}$ & $\begin{array}{c}\text { Cash Dis- } \\
\text { burse- } \\
\text { ments }\end{array}$ \\
\hline 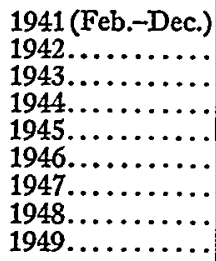 & $\begin{array}{l}533 \\
181 \\
323 \\
9^{.4} \\
219 \\
219 \\
820 \\
462 \\
.2\end{array}$ & $\begin{array}{c}356 \\
119 \\
239 \\
.3 \\
89 \\
197 \\
679 \\
393 \\
.2\end{array}$ & $\begin{array}{r}40 \\
32 \\
765 \\
2,374 \\
2\end{array}$ & $\begin{array}{r}30 \\
15 \\
376 \\
1,590 \\
1\end{array}$ & $\begin{array}{r}55 \\
45 \\
45 \\
45 \\
207 \\
45 \\
955 \\
5,000 \\
\ldots \ldots \ldots\end{array}$ & $\begin{array}{c}673 \\
266 \\
402 \\
45.4 \\
338 \\
296 \\
2,540 \\
7,836 \\
2.2\end{array}$ & $\begin{array}{c}441 \\
179 \\
300 \\
45.3 \\
326 \\
257 \\
2,010 \\
6,983 \\
1.2\end{array}$ \\
\hline
\end{tabular}

- Table corrected to nearest thousand except that sums less than $\$ 1,000$ have been corrected to nearest $\$ 100$.

$\dagger$ Including sinking fund requirements. ${ }^{\text {Is }}$

The effect of these large expenditures for maintenance, diesels and debt retirement ${ }^{14}$ on the cash position of the road is shown in Table V.

The corporate management felt that an adequate cash position at this time was somewhere between four and six million dollars. Thus payment of dividends during the last quarter of 1948 and the first three quarters of 1949 would have required the corporation to obtain a cash loan if cash resources were not to be further depleted.

\section{The Legal Issue}

The reasonableness of the Railway's expenditure programs must be analyzed in terms of their effect both on the corporation as a business entity and on the class of preferred shareholders as compared to other classes of security holders. In cases where the ability of the corporation to retain its customers and its credit position is involved, the results of the two analyses may be identical. But where a corporation embarks on financial policies that have no immediate relation to the operating soundness of the business and that deprive noncumulative

13 The sinking fund requirements were $\$ 45,000$ per year for the RFC note; $\$ 50,650$ for the first mortgage bonds; and $\$ 15,000$ for the general income bonds.

14 The reduction in long term debt since reorganization was as follows:

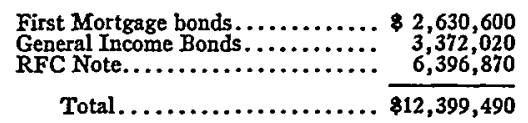

This reduction, however, was offset by the increase in equipment obligations from $\$ 2,735,904$ in February of 1941 to $\$ 12,955,855$ as of December 31, 1949. 
stockholders of dividends, these policies may be held oppressive and unreasonable despite the fact that they result in a saving for the corporation.

The Railway had a very strong contention as far as the programs of maintenance ${ }^{15}$ and dieselization ${ }^{16}$ were concerned. Both were arguably necessary to en-

TABLE V

\begin{tabular}{|c|c|c|c|c|c|}
\hline Date & Cash & $\begin{array}{l}\text { Capital } \\
\text { Funds }\end{array}$ & $\begin{array}{c}\text { Maintenance } \\
\text { Funds }\end{array}$ & $\begin{array}{l}\text { Temporary } \\
\text { Cash } \\
\text { Investments }\end{array}$ & $\begin{array}{l}\text { Total Cash } \\
\text { Resources* }\end{array}$ \\
\hline $\begin{array}{c}1947 \\
\text { Mar. } 31 \ldots \ldots \\
\text { June } 30 \ldots \ldots \\
\text { Sept. } 30 \ldots \ldots \\
\text { Dec. } 31 \ldots \ldots\end{array}$ & $\begin{array}{r}\$ 7,043,983 \\
6,794,552 \\
7,197,434 \\
7,579,587\end{array}$ & $\begin{array}{r}\$ 1,500,000 \\
1,500,000 \\
1,500,000 \\
754,125\end{array}$ & $\begin{array}{r}\$ 128,119 \\
128,119 \\
128,119 \\
52,214\end{array}$ & $\begin{array}{r}\$ 650,000 \\
650,000 \\
\cdots 300,000\end{array}$ & $\begin{array}{r}\$ 9,322,102 \\
9,072,671 \\
8,825,553 \\
8,685,926\end{array}$ \\
\hline $\begin{array}{c}1948 \\
\text { Mar. } 31 \ldots \ldots \\
\text { June } 30 \ldots \ldots \\
\text { Sept. } 30 \ldots \ldots \\
\text { Dec. } 31 \ldots \ldots\end{array}$ & $\begin{array}{l}6,465,805 \\
6,277,857 \\
6,402,306 \\
3,719,030\end{array}$ & 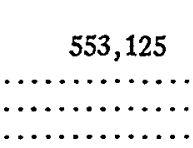 & $\begin{array}{l}52,214 \\
52,214 \\
50,214 \\
50,214\end{array}$ & $\begin{array}{r}380,000 \\
390,000 \\
290,000 \\
\ldots \ldots \ldots \ldots\end{array}$ & $\begin{array}{l}7,451,144 \\
6,720,071 \\
6,742,520 \\
3,769,244\end{array}$ \\
\hline $\begin{array}{c}1949 \\
\text { Mar. } 31 \ldots \ldots . \\
\text { June } 30 \ldots \ldots \\
\text { Sept. } 30 \ldots \ldots \\
\text { Dec. } 31 . \ldots .\end{array}$ & $\begin{array}{l}3,496,517 \\
2,692,764 \\
2,725,634 \\
4,499,130 \dagger\end{array}$ & $\begin{array}{l}\cdots \cdots \\
\cdots \cdots \\
\cdots \cdots \\
\cdots \cdots\end{array}$ & $\begin{array}{l}50,214 \\
50,214 \\
21,029 \\
\ldots \ldots \ldots\end{array}$ & $\begin{array}{l}\cdots \cdots \\
\cdots \cdots \\
\cdots \cdots\end{array}$ & $\begin{array}{l}3,546,731 \\
2,742,978 \\
2,746,663 \\
4,499,130\end{array}$ \\
\hline $\begin{array}{c}1950 \\
\text { Mar. } 31 . \ldots . \\
\text { June } 30 . \ldots .\end{array}$ & $\begin{array}{l}4,961,644 \\
4,896,494\end{array}$ & & & & $\begin{array}{l}4,961,644 \\
4,896,494\end{array}$ \\
\hline
\end{tabular}

* Exclusive of special deposits, sinking funds and other reserve funds.

† On December 2, 1949, the Railway borrowed $\$ 1,500,000$ at $3 \%$ interest, payable in three annual installments. $\$ 500,000$ was applied on December 26,1949 , to retire the $\$ 500,000$ principal amount of Wisconsin Central bonds that became due January 1,1950 . The remaining $\$ 1,000,000$ was added to working capital.

${ }^{15}$ It could hardly be denied that the Railway's track was in need of substantial rehabilitation. See note 12 , supra. Derailments caused by defects or improper maintenance of way and structures during the years 1941-48 ran well above the average for Class I railroads in the Western District. Much main line rail was too light for service and was not economical to maintain, -requiring extra ties, better balanced tie plates and more section labor. With the introduction of heavier locomotives in the early 1930 's, "ties became badly rail-cut and the rail line and surface bent, resulting in excessive tie renewals, other track maintenance costs, and frequent derailments." Examiner's Report, op. cit. supra note 12.

${ }^{18}$ Many of the Railway's steam engines were old, and replacing them with diesels avoided the necessity for an extensive equipment maintenance program. The plaintiffs argued that some of the diesels were purchased under conditional sales contracts which reduced the Railway's cash position more than equipment trusts would have done; and that the essential purpose of refinancing the diesels under equipment trusts was to conserve cash. See deposition of Edward T. Reidy, secretary of the Chicago Gt. West. Ry. Co., taken in Chicago, Ill., June 30, 1950 , p. 128. So, the reasonable way to buy diesels would have been to purchase under equipment trusts from the outset. There was some suggestion that the Railway was planning to reply that only a big dollar value equipment trust was marketable on Wall Street. However, in an impounding order of June 21, 1950, Judge Barnes found that the equipment trust method of financing was equally available in the earlier years and that had it been employed, substantial amounts of cash could have been utilized for other corporate purposes. 
able the Railway to retain its competitive position. ${ }^{17}$ Nor could the conduct of the road in retiring the RFC note in advance of maturity be considered "clearly unreasonable." The Railway was prepared to show that its indebtedness to the RFC would have had an adverse effect on its credit rating which was especially undesirable during a period in which it was endeavoring to obtain the most favorable possible terms for its financing of equipment purchases. There was also a saving of interest expense.

The plaintiffs anticipated these arguments by securing expert testimony to the effect that the Railway could have carried through its dieselization and maintenance programs and most of its RFC note retirement and could still have paid dividends simply by curtailing its purchases of first mortgage and general income bonds. The decisive question thus became the reasonableness of the bond retirement program.

When the court approved the 1941 Great Western reorganization, it probably did not foresee the great increase in earnings that railroads, including the Great Western, were to experience in the next decade. Net income in 1948, for example, was at that time the highest in the history of the road. Yet, because of the debt retirement program, no dividends were paid in 1948, although undeclared dividends ceased to accumulate in March of that year. If debt retirement were always to be considered an adequate excuse for refusing to declare dividends, then dividends could be passed almost indefinitely by a controlling group of common stockholders. This result would work a virtual fraud on investors who acquired the preferred stock of the Railway in the reasonable expectation of receiving some return on their investment. ${ }^{18}$

17 The programs resulted in substantial operating economies. The ratio of operating expense to operating revenue fell from $86 \%$ in January, 1946 , to $74 \%$ in July, 1950 , compared to an average drop from $72.5 \%$ to $71.6 \%$ for Class I railroads in the Western District. The relation of transportation expense to operating revenue dropped from $46 \%$ to $33 \%$ over the same period, while the average for Class I Western District roads fell from $35.5 \%$ to only $34.9 \%$.

${ }^{18}$ See the comment in Hazeltine v. Belfast \& M.L.H. R. Co., 79 Me. $411,423,10$ Atl. 328, 333 (1887) that funded debt is a normal part of the financial structure of all railroads and that to permit this debt to be paid off to the exclusion of declaration of dividends would be "an injustice amounting to cruelty in many cases." In Dohme v. The Pacific Coast Co., 5 N.J Super. 477, 68 A. 2d 490 (Ch. Div., 1949), discussed in Ashley, The Future of the Law of Noncumulative Preferred Stock in New Jersey: A Raid on the Inarticulate, 5 Rutgers L. Rev. 358 (1951), the corporation purchased during the period 1932-45 at large discounts bonds maturing in 1945. It was held that the use of the corporation's retained profits for this purchase of its own indebtedness did not deprive noncumulative preferred stockholders of their right to a dividend credit in those profits under the New Jersey rule. The court stated: "Annual net earnings or surplus consisting of withheld annual net earnings may in the discretion of the directors be applied to legitimate corporate purposes such as payment of debts . . . and other ordinary business requirements, and to the extent that they are so used the inchoate right of non-cumulative preferred stockholders in such funds is lost or terminated." Yet, "it was not within the normal operation of the business of the corporation to engage in the business of purchasing its own bonds at discounts. It would seem that the utilization of the earnings for such purpose, while an advantageous use of the corporate funds, is nevertheless not such a use as would deprive the preferred stockholders of their dividend rights in the funds so used." Ibid., at 491 and 497. 
The Railway's directors supported the propriety of the bond program by arguing that bond purchases reduced the fixed interest charges of the Railway, thereby placing it in a more stable long run financial position. ${ }^{19}$ The Interstate Commerce Commission had given support to this position when it noted that reorganizations, through which creditors and stockholders usually suffer a loss on their investment, are often the result of distributing surplus in prosperous years instead of reducing long term debt. ${ }^{20}$ But in terms of the directors' argument, the Railway would have placed itself in a much sounder financial position by retiring the fixed interest first mortgage bonds rather than the contingent interest general mortgage bonds. Yet Table IV shows that the heaviest retirement was of the general income bonds. As one of the attorneys for plaintiffs frequently brought out in pre-trial depositions, no railroad ever was forced into bankruptcy by inability to pay contingent interest. Indeed, with respect to the contingency of the interest, the remoteness of maturity, the fact that sinking fund requirements were not burdensome, and that the interest was tax deductible, the general income bonds were a very desirable form of indebtedness for the Great Western.

The Railway's second main argument in support of the debt retirement program was that it resulted in immediate concrete savings for the Railway. A study of 'Table IV shows that the bonds, particularly the general income bonds, were acquired at a substantial discount. In addition, the interest on the retired bonds was being saved. The Railway's comptroller stated in an affidavit that the debt retirement program as a whole, including both the bonds and the RFC note, produced a saving in principal amount on the debt retired of over $\$ 1,400,000$ and a saving in interest of about $\$ 1,000,000$ for the period 1946 through the first quarter of 1950. But the comptroller's figures present a deceptive picture.

First, earnings formerly paid out in interest were deductible, whereas retaining these earnings subjected them to the corporate tax. Second, the cash used in

19 The Railway could quote the court in its own reorganization: "It is a matter of common knowledge that one of the reasons why the railroads have so often been in financial difficulties, particularly during the times of economic stress, is the relatively large proportion of the indebtedness represented by fixed interest obligations." In re Chicago Gt. West. Ry. Co., 29 F. Supp. 149, 158 (N.D. Ill., 1939).

${ }^{20}$ ICC, 60th Annual Report 20 (Nov. 1946). See the ICC memorandum of Dec. 3, 1942, to the Illinois Central R. Co., set out in Guttman v. Illinois Central R. Co., 91 F. Supp. 285, 289-90 (E.D.N.Y., 1950), aff'd 189 F. 2d 927 (C.A. 2d, 1951): "[I]t would be a mistake, in the present tide of apparently revived earning power, to ignore the fact that [railroads] have a very heavy burden of debt and that it may be a crippling burden ... if earnings should radically decline. We have noted with approval that many of the managements are avoiding this mistake and are using the favorable earnings of the present ... to reduce fixed charges as rapidly as practicable. While stockholders may ... be disposed to object to such a policy, it is the stockholders who will suffer most in the event of future insolvency. They will, we believe, be shortsighted if, by insistence on immediate dividends, they jeopardize the continuance and possible expension [sic] of a program of debt reduction." In the Guttman case the railroad faced an early maturing funded debt. This fact played a decisive part in causing the court to declare that the railroad's decision not to declare dividends on its noncumulative preferred stock was reasonable. 
the debt retirement program could have been used to purchase the diesels outright. Instead, the diesels were financed under equipment trusts bearing $2.75 \%$ interest. Thus the interest saved, in these terms, on the bonds should be reduced by the interest paid under the equipment trusts. ${ }^{21}$

The method of bond purchases was also subject to the criticism that economy had been sacrificed to a desire for speedy retirement of a large amount of bonds. In January of 1948, with general income bonds selling at 57, the Railway invited tenders. Between that time and the date of acceptance in March of 1948, the Railway purchased some $\$ 800,000$ principal amount of general income bonds on the open market. This played a material role in driving the price of the general income bonds up to $66.5-67$. Tenders up to 70 were accepted, with the average about $68 . \$ 806,000$ principal amount of general income bonds were purchased on the tenders. Thus the Railway was competing against itself by seeking low tender offers while at the same time bidding the market price higher, with the result that bondholders naturally raised their tender price.

The Railway's position becomes even more vulnerable when the exchange plan is considered. Its stated purpose was to provide preferred shareholders with an immediate return on their investment. Yet there was no reason why the Railway could not pay directly to the preferred stockholders the cash that it was prepared to pay debenture holders under the plan. The Railway emphasized that interest on the debentures would be tax deductible. Assuming a $38 \%$ tax for each $\$ 1.00$ available for distribution, the debenture holder would receive the full $\$ 1.00$ as interest, while the preferred stockholder would get only $62 \xi$ as a dividend. But this solicitude for the welfare of the preferred stockholders was inconsistent with the fact that in the proposed exchange, the preferred stockholders would suffer a loss of both par and market value.22 Moreover, plaintiffs had considerable evidence that the ultimate aim of the plan was to effect a total or partial elimination of the outstanding preferred stock. Finally, it seems a bit unusual for the Railway to advance a plan that would create additional debt in the form of debentures at the very time when it appeared so anxious to reduce its outstanding bonded indebtedness.

Were the bond retirement program considered apart from the exchange plan, the plaintiffs might have been unable to show that the purchase of bonds was "clearly unreasonable" with respect to preferred shareholders. But the exchange

${ }^{21}$ The Railway argued that depreciation allowed on the diesels made available enough cash to wash out the actual charge, so that payments on them should not be considered. The idea of refinancing the diesels was to "get within our depreciation." Deposition of William N. Deramus III, president of the Chicago Gt. West. Ry. Co., July 18, 1950, p. 40. But this line of argument is simply a sophisticated way of saying that the refinancing helped to conserve the cash position of the company. See note 16 supra. It does not destroy the validity of offsetting new equipment trust interest charges against alleged savings of interest from bond retirement, for the Railway would be charging depreciation on the diesels no matter what method of financing had been employed, whether equipment trusts or flat cash purchase.

22 See notes 25 and 26 infra. 
plan fitted too neatly into plaintiffs' theory of the case to be altogether coincidental.

As already noted, in April of 1948 the Railway filed its exchange plan with the ICC. Evidence concerning the programs of dieselization, maintenance and debt retirement was presented to show why dividends were not likely in the near future. In June 1948, the trial examiner, H. C. Howard, issued a proposed report recommending disapproval of the plan. ${ }^{23}$ The execution of the exchange would leave the road with more long term debt than equity $(58 \%-42 \%)$. Since the debt-stock ratio $(42 \%-58 \%)$ established for the road at reorganization was the result of extensive study, Howard was reluctant to permit such a significant change until "the most compelling necessity is shown therefor. Such a showing has not been made by the applicant." "24 Howard also stated that the preferred stockholders would suffer a loss of value in the exchange ${ }^{25}$ and, except for the tax advantage, nothing would prevent the Railway from paying directly to the preferred stockholders the cash that would go to debenture holders under the plan.

Rehearings were held on January 4 and June 8, 1949. The preferred stockholders intervened in the latter hearing. The main new evidence for the Railway in the January 4 hearing was the further retirement of debt and the achievement of a debt-stock ratio of $33 \%-67 \%$ as of October 31,1948 . On June 8 the Railway presented a poll of preferred stockholders which tended to indicate that less than $25 \%$ of the outstanding shares would be exchanged, and that the debt-stock ratio would thus not be as adversely affected as by a $100 \%$ exchange.

Howard proposed a second adverse report on August 24, 1949, and the Railway thereupon withdrew its application and abandoned the plan of exchange. Howard reiterated that preferred stockholders would suffer a loss in the exchange ${ }^{26}$ and that cash available as interest on the proposed debenture was equally available as dividends on the preferred stock. He considered unimportant the fact that the interest on the debenture would be tax deductible, in view

${ }^{23}$ ICC Examiner Howard's proposed report on the application of the Chicago Gt. West. Ry. Co., F.D. 16068 (June 23, 1948).

${ }^{24}$ Ibid., sheet 4.

${ }^{25}$ At par the exchange would be $\$ 50$ (par value of one share of preferred stock) plus $\$ 7.50$ accumulated dividends for $\$ 30$ ( $\$ 20$ par value debenture plus one-fifth of $\$ 50$ par value share of common stock). At market, the exchange would be $\$ 16-17$ for $\$ 12$ on the estimate that the $\$ 20$ debenture would sell at $50 \%$ of par. The next senior issue, the general income bonds, were then selling at 65 .

${ }^{26}$ The par comparison would still be $\$ 50$ plus $\$ 7.50$ to $\$ 30$. The market price of $\$ 13-14$ to which the preferred had dropped still exceeded the $\$ 12$ estimated market value of the debenture and $\frac{1}{5}$ share of common stock. The Railway's argument was that loss of value was intended to eliminate profit from the resale of new common stock and debentures at a price higher than the market value of the exchanged preferred stock as a motive for participating in the exchange. If there was a prospect of profit from resale of the new securities, a much greater number of preferred holders would exchange, and the debt-stock ratio of the Railway would be adversely affected. 
of the fact that the Railway had just reduced the amount of that deduction by its extensive debt retirement program. ${ }^{27}$

Howard's main point was that, if the Railway felt reluctant to pay dividends because the best interests of the road and the public would be served by applying available cash to dieselization and maintenance, then it was inconsistent to permit the creation of a charge on earnings by the substitution of funded debt for stock that would compel the corporation to curtail these programs. ${ }^{28}$

From the standpoint of the preferred shareholders, the Railway's debt retirement program, viewed in light of the exchange plan, looked like an effort to reduce outstanding debt so that the creation of new debt in the form of debentures would not create a stock-debt ratio unacceptable to the ICC. The combination of tenders and open market purchase could thus be fitted into plaintiffs' case. Between January and March of 1948 the Railway was in an unseemly hurry to cut its bonded indebtedness in time for the first ICC hearing in April of 1948. The decision to concentrate on purchasing general income bonds rather than first mortgage bonds could be explained on the basis that the general income bonds were available at a larger discount. Thus their retirement would reduce the par value of outstanding indebtedness more than would expenditure of the same amount of money for retirement of the first mortgage bonds, and the ratio of debt to stock would therefore appear more favorable to the ICC.

The pattern which the stockholders developed from the series of corporate transactions herein described may be summarized as follows: The debt retirement program, together with the dieselization and maintenance programs, were devices to excuse the halting of dividends. The debt retirement program served the additional function of making the exchange plan palatable to the ICC. The halting of dividends, in turn, had three purposes. First, after the maximum accumulation on the preferred dividends had been reached, the earnings of the Railway could be retained for the benefit of the controlling group of common stockholders. Second, the halting of dividends gave this group a colorable argument for presenting the exchange plan to the ICC. And third, once the plan had been approved by the ICC, the halting of dividends was to be the coercive factor that would gradually compel more and more preferred stockholders to accept the disadvantageous exchange.

Not only is this pattern consistent with the facts, but it offers a convincing

${ }^{27}$ Howard also noted that the preferred stock had been given a voting majority for their protection in the reorganization, and that the exchange plan would shift control to the common stock.

28 "No reasonable and prudent management will declare and pay a dividend until provision has been made for the meeting of all current corporate needs, nor should it create a charge upon corporate earnings in derogation of such needs." ICC Examiner Howard's proposed report on the application of the Chicago Gt. West. Ry. Co., F.D. 16068, sheet 7 (August 24, 1949). This analysis appears to beg the question by assuming at the outset that the programs embarked on by the Railway were in fact in the best interests of the road and the public. 
explanation of otherwise highly puzzling acts on the part of the Railway, such as the vigorous pressing of an unreasonable exchange plan and the method, composition and timing of the bond retirement program. In an oral opinion which concluded the fee hearing, Judge Barnes commented: "I am satisfied that a plan was formulated to mulct the preferred stockholders of this railroad. . . . As far as I can see, there wasn't any defense to [plaintiffs'] lawsuits."29

\section{The Tactical Issues}

Problems of strategy created almost as many difficulties for the preferred stockholders as did problems of proof. The first question was whether or not to intervene in the ICC hearings. On one hand, the conclusion of the ICC would not be determinative of any issue in the stockholders' action, since the question before the ICC was whether the plan was compatible with the public interest ${ }^{30}$ while the lawsuit was framed in terms of the interests of the preferred shareholders. Nevertheless, the stockholders decided to intervene in order to avoid the contention that they had not exhausted their administrative remedies before turning to the courts. The plaintiffs further believed that, had the ICC approved the plan and thus lent its weight to the Railway's position, the difficulty of carrying the dividend suit would become too great.

Howard's second adverse report was filed in August 1949. The Railway's motion to dismiss the Zimmerman complaint was denied in October. On December 1,1949 , the Railway declared a partial dividend on the preferred stock, and the next day it borrowed $\$ 1,500,000$. Full quarterly dividends were declared in March, June and September of 1950. Attorneys for the plaintiffs viewed this action as an attempt to "take the wind out of their sails." The attorneys further felt that the pressure of their suit had virtually compelled the Railway to resume declaration of dividends, and that they were entitled to reimbursement from the fund made available by their efforts. Therefore, prior to the payment of the last three dividends, they moved that a portion of each dividend be impounded to insure the payment of plaintiffs' attorneys' fees and their costs and expenses in the event that the plaintiffs should ultimately win on the merits. These motions were granted, the trial judge stating "that there are reasonable grounds to believe that the declaration of (these) dividends . . . came about largely because of the efforts of plaintiffs and their counsel in connection with the prosecution of these suits and the work incidental thereto."

Among these "reasonable grounds" was the Railway's sudden shift from that taken before the ICC. It was there urged by the Railway and confirmed by the

${ }^{29}$ Trans. of Proceedings at 697-98, Harris v. Townsend, Consolidated Civil Action No. 49 C 462 (N.D. Ill., June 21, 1951).

${ }^{30}$ See 41 Stat. 494 (1920), as amended, 49 U.S.C.A. $\$ 120$ (a)(2) (1951). ICC Examiner Howard felt constrained on several occasions to remind counsel for the intervening stockholders of this fact. See, e.g., ICC Hearing Docket No. F.D. 16068, stenographer's minutes, p. 205 (June 8, 1949).

31 Findings of fact, June 21, 1950, p. 9, by Barnes, J. Similar findings were made in March and September. 
trial examiner ${ }^{32}$ that no dividends would be paid for an indeterminate period in the future.

In reply, the Railway argued that conditions had changed considerably from those on which the Trial Examiner had based his estimate. The dieselization program was virtually completed, and the diesels already purchased under conditional sales contracts had been refinanced under equipment trusts. Thus no large cash down payments for diesels would be necessary in the future, and annual payments were reduced, all of which helped to conserve the cash position of the corporation. The Railway could also point to increased earnings in 1950, and savings in fuel and labor costs - called surprisingly large by the Railwaythat were already resulting from utilization of the diesels. The Railway's cash and net current asset position had improved on December 31, 1949, as compared to December 31, 1948. And the debt retirement program had ended as far as the RFC note and the first mortgage and general income bonds were concerned, ${ }^{33}$ thus removing another drain on cash.

The plaintiffs contended that, if the $\$ 1,500,000$ which the Railway borrowed on December 2, 1949, be ignored, the Railway was in a weaker cash and net current assets position on December 31, 1949, than on December 31, 1948. In addition, 1949 earnings ran below those of 1948. The Railway suggested in reply that this slump in income was chiefly attributable to the increased maintenance program. Thus, if maintenance had been held at the 1948 level, the difference of $\$ 1,668,199$ less $38 \%$ tax, or $\$ 1,034,283$, would have been added to income.

The Railway appealed from the impounding orders to the Court of Appeals for the Seventh Circuit. At this point a committee of preferred stockholders was formed which was permitted to file an amicus curiae brief in opposition to the impounding orders. The committee claimed it represented the true interests of the preferred stockholders in opposing the impounding of their dividends and in backing what the committee considered wise and sound decisions of the Railway in postponing dividends while the property was being built up. In their Circuit Court briefs, both the Railway and the committee challenged the true class nature of the litigation and denied that the plaintiffs fairly and adequately represented the class. ${ }^{34}$ The committee also began to solicit authorizations from preferred stockholders.

23 "The applicant's corporate requirements are such that for the next five or six years it is probable that no dividends upon the preferred can be paid." ICC Examiner Howard's proposed report on the application of the Chicago Gt. West. Ry. Co., F.D. 16068, sheet 7 (August 24, 1949).

${ }^{23}$ While only $\$ 2,400$ face value of first mortgage and general income bonds were retired in 1949 , the Railway retired $\$ 500,000$ Wisconsin Central bonds and $\$ 1,053,424$ of equipment obligations. There was, however, no such substantial debt retirement in advance of maturity as in 1948. Several directors included among their reasons for declaring a dividend the increased efficiency of the corporate management since William $\mathrm{N}$. Deramus III had assumed the presidency of the Chicago Great Western in May of 1949. And reduced fears of an impending depression had influenced one director to vote for the dividends.

31 The thrust of defendants' argument was that, if the proceeding were not a true class action, a holding for the railroad would be no defense against the suits of preferred stock- 
The response of plaintiffs was twofold. First, they charged that the committee owned a large amount of common stock, which rendered its representation suspect, and that although purporting to be opposed to the merits of the litigation, its purpose was only to oppose the impounding orders and the allowance of fees to the plaintiffs' attorneys. Second, they entered into competition with the committee in the solicitation of authorizations. The strategy of the plaintiffs was explained by one of their attorneys in this way: "[I]f the . . committee, unopposed by the plaintiffs, should obtain a half or two-thirds of the class to sign authorizations, I felt that that could have a serious adverse and conceivably inarticulate psychological effect on this court and on the Court of Appeals, which we, in duty to the class, could not permit to happen." ${ }^{35}$ As it turned out, the plaintiffs lost the battle of authorizations. ${ }^{36}$

The Circuit Court reversed the impounding orders, stating in a brief per curiam opinion:

Plaintiffs make no claim that defendant Railway Company is insolvent or for any reason unable to meet its obligations as they mature.... Whether this is a true class action has not yet been and can not be determined until after production of evidence upon the merits. It seems clear to us, therefore, that the orders were unjustified prior to determination of the merits, and that, before such event occurs, any such order is wholly premature and unsupported in law. .... ${ }^{37}$

holders not parties thereto. Defendants also pointed to Pelelas v. Caterpillar Tractor Co., 113 F. $2 d 629,632$ (C.A. 7th, 1940): "It is a condition precedent to the existence of the right to maintain a class action that the court find that the plaintiff's suit will fairly insure the adequate representation of all." The committee made much of the fact that plaintiffs represented at most $3 \%$ of the preferred stockholders, and that the committee itself had received authorizations from several times that number.

${ }^{35}$ Trans. of Proceedings at 60 61, Harris v. Townsend, Consolidated Civil Action No. $49 \mathrm{C}$ 462 (N.D. Ill., June 18, 1951). Compare a letter by the committee, Aug. 25, 1950, requesting authorizations "because it believes that its participation in the litigation will carry more weight if the courts are aware of the number of Preferred Stockholders who oppose the actions of the plaintiffs."

${ }^{36}$ The difficulty of overcoming the initial presumption in favor of the corporation is thus seen to be as great in dealing with stockholders as it is with the courts. Furthermore, the corporation is in a powerful position to influence the opinions of its shareholders directly. In a letter of March 30,1950, to the preferred stockholders, the president of the Great Western commented that a part of the March dividend had been impounded and added: "The directors and the management sincerely desire to place your property in a sound position and pay dividends. Stockholders are entitled to income on the investment in such securities. It is, however, necessary to build sound value into any enterprise before equity interests can be assured of continuing a dependable income. The Company's entire objective has been and is to so conduct its affairs that the locomotive and equipment purchases and its track improvement program could progress more rapidly, with lower interest charges and economy in operation, than could otherwise be hoped for." It may be remarked that the letter was completely silent about the debt retirement program.

${ }^{37}$ Zimmerman v. Chicago Gt. West. Ry. Co., 185 F. 2d 399, 400 (C.A. 7th, 1950), cert. denied, 340 U.S. 934 (1951). The result seems unsatisfactory. If plaintiffs' attorneys were to prove on the merits that their efforts had caused the declaration of dividends, they would be 
Beginning in September 1950, intermittent efforts were made to settle the main litigation out of court, and various proposals and counterproposals were offered. However, no agreement was reached until, on May 1, 1951, as one of the Zimmerman attorneys arose in court to make the opening statement on behalf of the plaintiffs, an attorney for defendants suggested further settlement negotiations. An agreement was worked out among the attorneys that night, and approved by the trial court as fair and reasonable after notice to all preferred shareholders.

By the time of the settlement, the Railway had already resumed regular dividend payments on the preferred stock and had paid $\$ 1.12 \frac{1}{2}$ per share in liquidation of arrearages, leaving an unliquidated arrearage of $\$ 6.37 \frac{1}{2}$ per share, or $\$ 2,333,913$. The agreement provided that the Railway would in all events continue to pay its regular dividends for the balance of 1951 and that thereafter, until such time as the arrearages were fully paid, the Railway would pay regular dividends to the extent of $60 \%$ of the "available net income."

As to the arrearages, the Railway agreed to pay $\$ 3.00$ per share by July 16 , 1951 , and, starting in 1952, to devote the $60 \%$ of "available net income" less regular dividend payments exclusively to additional dividends until the remaining arrearages of $\$ 3.37 \frac{1}{2}$ per share were completely eliminated.

The Railway further agreed to pay reasonable costs and attorneys fees, as allowed by the District Court, reserving, however, the right to appeal. All defenses in connection with the class nature of the proceedings or the extent to which the plaintiffs fairly and adequately represented the class were waived by the Railway and the intervening stockholders' committee.

While the Railway did not agree to pay the $\$ 1,487,297$, or $\$ 4.06 \frac{1}{4}$ per share, undeclared and not accumulated, the plaintiffs regarded the Railway's agreement to pay attorneys fees (and thus to enable the preferred shareholders to receive the full dividends provided for under the settlement agreement) as a settlement of the claim. ${ }^{39}$

entitled to compensaton from those very dividends. Yet once the dividends were completely distributed to several thousand stockholders, it would become virtually impossible to levy on them for compensation.

${ }^{38}$ The agreement defined "available net income" as income after fixed charges, less sinking fund payments and capital fund requirements for the first mortgage and general income bonds, interest payments on the general income bonds, and any amounts necessary to restore to the capital fund accounts monies used to pay interest on the first mortgage bonds; and plics the amount, if any, by which maintenance expense for the year should exceed $19 \%$ of the Railway's total operating revenues, and the amount, if any, by which the amortization of defense projects under Necessity Certificates should exceed the normal rates of depreciation established by the ICC. These last two provisions served as protection for the plaintiff stockholders. It was necessary to place some limit, as far as the declaration of dividends was concerned, on the controllable item of maintenance expense. And rapid amortization of defense projects would materially reduce income now as against the future. But the provisions were flexible in that the actual expenditure for maintenance was not limited and the emergency amortization basis of depreciation could still be utilized for tax purposes.

${ }^{39}$ In accordance with the settlement agreement, the Railway applied to the ICC for permission to borrow money for working capital in order to carry out the terms of the agreement, 
A comparison of the terms of the settlement agreement with the relief requested in the Zimmerman complaint shows that the objectives of plaintiffs were substantially attained. Regular dividends had been resumed on the preferred stock; the Railway had agreed to liquidate the accumulated arrearages; a settlement had been made of dividends undeclared and not accumulated; and the Railway had abandoned its exchange plan. ${ }^{40}$

and on June 6,1951 , the ICC approved an issue of $\$ 3,000,000$ of promissory notes by the Railway at an interest rate of $3 \frac{1}{2} \%$.

${ }^{40}$ On June 21, 1951, Judge Barnes allowed $\$ 500,000$ as "the usual and customary, fair and reasonable fee for services such as have been rendered by counsel for complainants in these two cases." Trans. of Proceedings at 700, Harris v. Townsend, Consolidated Civil Action No. $49 \mathrm{C}$ 462 (N.D. Ill., 1951). The award appears fair in light of the difficulty of stockholder suits. In addition, the contingency of the fee and the infrequency of success make the suit a highly risky one for attorneys to undertake. If the fee is not made liberal enough to encourage competent counsel to undertake such cases, plaintiff stockholders will be helpless and the potential therapeutic effect of vigilant shareholder supervision over the decisions of corporate directors will be lost. On June 17, 1952 (No. 10481, Advance Sheet), the Seventh Circuit reduced the fee allowance to $\$ 350,000$. The court found that time spent on the impounding orders and solicitation of preferred stockholders added nothing to the value of the services rendered (but see text and notes at note 35 supra), and that the settlement agreement only provided "some additional safe-guards" for dividends "due under any circumstances." (Query whether dividends are in fact "due" until they have been declared.)

In passing, the court noted "the unwelcome aroma of the tactics of a pressure group" in what it felt to be the extreme liberality often shown by lawyers in applying for fees. But the $\$ 350,000$ fee approved by the court, which amounted to an hourly charge of roughly $\$ 50$ for every lawyer associated with the case, irrespective of his standing in his firm, was still substantial. That such a fee was approved despite the court's fear that it might "seem extravagant not only to the public but to other members of the bar," bears witness to the court's appreciation of the complexities and risks of stockholder litigation. 